\title{
A Hole in the Wall; A Rose at a Checkpoint: The Spatiality of Colonial Encounters in Occupied Palestine
}

\author{
SHERENE RAZACK ${ }^{1}$ \\ Ontario Institute for Studies in Education, University of Toronto
}

\begin{abstract}
This article reflects on the spatial arrangements that memorialize power on the bodies of the colonized in occupied Palestine. These are the reflections of someone whose research is focused on the Canadian context. I attempt here to have a conversation with those scholars who are more conversant with the Israeli/Palestinian context than I, reading them through the prism of my own extremely brief experience of occupied Palestine, and through my research on violence against Aboriginal peoples in Canada. I focus on the physical encounter between colonizer and colonized, on the way that spaces express power arrangements that operate on the bodies of the colonized, turning them into small animals scrambling over rocks, or rats prodded and poked to make their way through a maze. The same spatial arrangements confirm colonizers as rightful owners of the land, convincing them who they are. The wall, the shouting at checkpoints, the power to arbitrarily stop and search, these must assist the 18 year old soldier wielding a gun to banish the ghosts on the landscape, the Arab faces, the outlines of buildings, the old Arabic names - anything that suggests that in truth, the land is Arab land.
\end{abstract}


Space is one way to think about the violence of settler states towards the Indigenous populations they have dispossessed. In June of 2007, I was invited to share with Palestinian scholars my research on the spatiality of settler violence against Canada's Aboriginal peoples. The spatiality of power relations has become an important methodological directive for those of us who work on white settler societies. Racial power is anchored spatially, as Rhadica Mohanram succinctly put it, and deconstructing how power operates in and through space (a process I refer to elsewhere as unmapping) is one way of tracking the race and gender arrangements of settler societies. $^{2}$

There is a distinct spatiality to the three most salient features of settler colonialism: the making of the colonizer as modern and the colonized as pre-modern; the eviction of the colonized from the law and thus from civilized space; and the violence that marks the colonial encounter. In my address to the conference, I offered various examples of colonial or racial violence in Canada: Aboriginal men who are driven out of city space by the police, and left to walk back into town in subzero conditions, an eviction many do not survive; Aboriginal women working as prostitutes who often "disappear" and are later found murdered and dumped in spaces outside of civilized life; and alcoholic Aboriginal men who die under mysterious circumstances after being apprehended by the police, often with signs of violence on their bodies (boot prints, handcuff marks, and so on). I suggested that what is discernable in each of these moments of violence is an ongoing colonialism - full of legally authorized evictions to zones where the law 
does not operate and where violence can take place with impunity. The sequential features of this kind of abandonment are: spatial segregation that is legally produced and authorized; a reduction of peoples to a diminished state of existence; violent evictions from settler space, evictions that function as identity making processes for the colonizer. Law largely forgives the perpetrators of colonial violence. It often does so either by viewing the instances of violence as exceptional and/or considering that the victims brought the violence on themselves - it is they who are dysfunctional, sick, prostituting themselves, posing a security threat, and so on.

The richness of the exchanges that took place at the conference "Palestinian Voices: Feminist Thought As A Tool for Resistance" in Nazareth and Birzeit, and throughout my visit to Israel/Palestine, stimulated a number of additional thoughts on the spatiality of colonial arrangements. Most of all, perhaps because this was my first experience of militarized occupation and with the myriad ways in which daily life is militarized for occupied populations, I came to appreciate in a new way how power is memorialized (to use Achille Mbembe's evocative phrase) on the bodies of the occupied, an awareness gained largely from my experience of the wall being built by Israel to physically separate itself from Palestine. Put another way, I saw parallels between the imprinting of colonial power on Aboriginal peoples in Canada and the same processes in Palestine.

This article reflects on the spatial arrangements that memorialize power on the bodies of the colonized in occupied Palestine. These are the reflections of someone whose research is 
focused on the Canadian context. I attempt here to have a conversation with those scholars who are more conversant with the Israeli/Palestinian context than I, reading them through the prism of my own extremely brief experience of occupied Palestine, and through my research on violence against Aboriginal peoples in Canada.

\section{At the Level of Skin: The Checkpoint}

In her brilliant article on the spatiality of Apartheid, South African scholar Lindsay Bremner argues that it wasn't a wall or even the Bantustans that most distinguished apartheid: Instead it was the countless instruments of control and humiliation (racially discriminatory laws, administration boards, commissions of inquiry, town planning schemes, health regulations, pass books, spot fines, location permits, police raids, removal vans, bulldozers) and sites of regulation and surveillance (registration offices, health clinics, post offices, recruitment bureaus, hostels, servants rooms, police spaces, courtrooms, park benches, beer halls) that delineated South African society during the Apartheid years and produced its characteristic landscapes. ${ }^{3}$

Daily "acts and rituals were transformed into acts of segregation and humiliation that accumulated into an omnipresent violence of everyday life. In this obscene enactment of power, apartheid's walls were nowhere and everywhere." Bremner concludes: 
Apartheid operated as a bio-politics of discrimination and disqualification at the level of the skin. The skin was the site where the categories of violence associated with borders were performed. ${ }^{4}$ (emphasis added).

Bremner thus invites us to consider that the landscape of apartheid was one of encounters as well as separations, and that colonial power is power exercised on bodies. In cities, while each race group had its own residential area and type of housing, there were carefully planned zones of interaction. Bantustans were in fact fragmented and discontinuous. They were not meant to enclose but to force residents into migrant labour. Thus, "Apartheid's characteristic spatial forms were designed to be porous, to regulate the body in motion. They produced a narrative not of closure, but of hundreds of thousands of entries and crossings." "It is this porousness that most strikes the first time visitor about the wall separating Palestinians and Israelis, a porousness that suggests both where and how the bodies of the occupied are imprinted with the power of the occupiers.

\section{Memorializing Power}

Power must be inscribed on the bodies of the colonized, a "memorializing" as Mbembe puts it, that is in evidence at moments of contact. Explaining what he terms "graphism" as a principal colonial technology under Apartheid, Mbembe describes this process for Black miners:

Graphism consisted foremost in tracing marks on the body and on the territory. 
But the main site of inscription was the black body itself. It could be searched everyday at the end of the shift in the mines. It could be stripped naked, required to jump over bars. Hair, nose, ears, or rectum could be scrutinized with meticulous care. Floggings with a sjambok (leather whip) or tent rope, or striking with fists were the rule. In order to memorialise themselves, public and private powers traced their signs on the naked flesh of the black body. They belabored it and laid it bare through various techniques: tattooing, excising, carving, sacrifying, mutilating, or encircling. ${ }^{6}$

To memorialize power on the bodies of the colonized requires an apparatus. The Apartheid racial state had to organize segregation, jailing, eviction, and "floating spots where "inhumanity" could be immediately experienced in the body as such. Around them was instituted a field of visibility and surveillance, hierarchies and inspections."7 One thinks here of the floating checkpoints that are 'sprung' on Palestinians anywhere and at anytime.

In contemporary occupied Palestine, the wall with its many checkpoints and openings provides a case in point of graphism. While a great deal has been written on how the Wall functions to impoverish and disrupt Palestinian life, less has been said about its effects on individual bodies. In Nadera Shalhoub Kevorkian's work Facing the Wall, one sees how girls and women negotiate their daily crossings. ${ }^{8}$ At checkpoints, girls learn that their own communities are limited in their capacity to protect them from all kinds of violence - the 
violence of the Israeli soldiers but also the patriarchal violence of their own communities as they rush home to avoid curfew. Parents also impose restrictions on girls' activities, fearing that they will be harassed by soldiers. In effect, the wall teaches girls and women in an embodied way, that they are under surveillance and condemned to a lesser life. Such effects are clearly gendered in that they do not apply in the same way to boys as to girls. Girls who are forced to climb over hills, ditches and walls, to take clandestine routes and to risk search and seizure, are denied the bodily integrity of full citizens but also the modesty that under patriarchy would otherwise mark them as the sex to be protected. Palestinian girls are thus evicted from femininity and bear all the attendant, gender-specific risks of such an eviction.

\section{"See How We Jump": A Hole in The Wall at Jeeb}

To first time visitors, the sheer magnitude of the wall (in places where it is a 25 foot concrete barrier) immediately begins to have an impact on the body. One feels small, vulnerable and hemmed in. The impression of a tremendous power is nowhere more overwhelming than when one stands in the very small space between the wall and the apartment block or building it has simply cut off. Suddenly, someone's bedroom window now looks out on a concrete monstrosity one can almost touch. The wall casts a huge shadow on the buildings it has isolated and it reaches quite literally into daily life, squeezing life's activities into smaller and smaller 
spaces. Fanon's description of the world of the colonized as "a world without spaciousness" is particularly relevant here. ${ }^{9}$

The process of inscribing power on bodies is aptly captured in the response of a Palestinian man whose efforts to cross through an opening in the wall were being filmed by a French television crew. "Show them [French viewers] how we jump," he suggested with illconcealed irony. ${ }^{10}$ Openings in the wall, parts somehow left unfinished, or parts of the wall that can be scaled produce Palestinians as pre-modern, animal-like in their movements, clandestine and illegitimate as they navigate the enormous blocks of concrete, the barbed wire and the electrified fences. At one such opening at Jeeb, ${ }^{11}$ I observed a young man jumping perilously from building roof to concrete block to make his way back into Jeeb from Jerusalem. The man seemed small and thin against the massive concrete and his movements brought to mind goats as they scramble up mountain slopes. Others, less agile and perhaps less willing to risk life and limb, made their way to Jerusalem through the opening at a lower level by climbing over the concrete slab that had not yet been placed upright and fixed in its place. One woman carried her computer bag and it swung dangerously as she climbed, aided by some young men.

The lessons for the body are clear: Palestinians do not simply walk or ride to work or school but instead scramble, crawl and climb. From the roof of a nearby almost empty apartment building, one can see the full extent of the wall and watch the progress of the people climbing through the opening. At one such moment, two military jeeps materialized out of nowhere. The 
woman carrying the computer, whose Black chador was visible from on high as she made her way through open expanse, now stood frozen as a deer caught in headlights. The jeeps came from each direction, cutting off all possibility of escape and making clear that the wall is also an "apparatus of capture."12 Soldiers regularly tear gas these openings in the wall, making Palestinians 'jump' and flee, this time in physical pain.

\section{Asymmetrical Intimacies}

Reading online the accounts of young Palestinians at checkpoints, it is clear that the checkpoint, like the opening in the wall, must physically reduce the body to a state of insignificance, and to the status and movements of a trapped animal. The rituals at the checkpoint, Kafkaesque in their absurdity, are nonetheless productive in the same way as the imposed climbing is; they imprint the power arrangements of colonialism on the bodies of the colonized, laying bare for all to see and to know in an embodied way who can have human dignity and who cannot.

The young soldiers who check the papers of Palestinians cannot hope to be making any kind of realistic assessment of who must cross and who must not, precisely because there are many crossings. As under Apartheid, when Black people from the townships provided the labour for whites in the cities, so too Palestinians must continually journey to Israel for the purpose of work, school, medical care, and family interactions. What, then, is the purpose of checkpoint 
rituals, if they do not serve any practical purpose? The rituals themselves offer a clue. When boys and girls and young adults describe their experiences of passing through the Qalandiya checkpoint, for instance, they describe the shouting that accompanies the many stages of checkpoint ritual. Twenty year-old Muhammed Maher comments: "The checking procedure takes some 15-20 minutes. First I put my ID into a small hole, then they shout at me to go to the body checking process." 12-13 year olds at Ahed secondary school in al-Ram describe the same shouting as they move from the first set of revolving doors, through the X-ray process and then the checking of ID on children too young to possess it. ${ }^{13}$ The checkpoint is an asymmetrical intimate encounter whose asymmetries must be performed. We might think, then, of the structured security encounter as a time and place where occupied and occupier, each comes to know his place in the scheme of things. In short, the identity-making processes at work at the checkpoint comes into full focus.

While Palestinians must learn of continuous surveillance and of the febrile texture of the encounter, so too the Israelis must find in these rituals their own sense of entitlement and be able to convince themselves that they have successfully controlled the movements of anyone who encroaches on the settler's claim. Fanon's classic words about "the language of pure force" of colonial police come to mind:

In the colonial countries, on the contrary [to capitalist countries where force is differently expressed] the policeman and the soldier, by their immediate 
presence and their frequent and direct action maintain contact with the native and advise him by means of rifle butts and napalm not to budge. It is obvious here that the agents of government speak the language of pure force. The intermediary does not lighten the oppression, nor seek to hide the domination; he shows them up and puts them into practice with the clear conscience of the upholder of the peace; yet he is the bringer of violence into the home and into the mind of the native. ${ }^{14}$

Fanon's point speaks to the wall's overt function and to the language of pure force. However, as many of the contributors to the outstanding collection Against the Wall point out, the wall has both overt and covert functions. Rucharma Marton and Dalit Baum observe that the wall is both a defense from bullets and a defense from seeing. With respect to the latter, the wall has the important psychological advantage of enabling those on the Israeli side to imagine that what lies beyond the wall, that is, what they don't see, does not exist. If seeing holds out the possibility of understanding, Marton and Baum wryly comment, then the wall blocks the possibility of "insight" into the conditions of the lives of Palestinians. ${ }^{15}$ As in Aldous Huxley's Brave New World, the war takes place on far away alien worlds.

If we focus on the covert functions of the wall, as Marton and Baum do, and follow their arguments about what the wall does, we can consider the wall as enabling a fantasy of control and conquest. For the occupier, the wall serves to keep at bay his terrible anxiety that 
he is in fact not in control. Marton and Baum characterize the psychic underpinnings of what goes on for the soldier and the state at the checkpoint as an obsessive disorder, a belief that the repetition of certain actions (a cleansing, a checking) will prevent death. They insightfully observe:

Rituals are created with the aim of self-preservation from contamination, diseases and deaths. These rituals are constantly refined in arbitrary ways. The person knows deep down that there is no total control; thus the anxiety is ever present, reinforcing these rituals, which may take over an obsessive person's life, achieving precedence over all aspects of life, requiring an ever-growing investment of resources. ${ }^{16}$

Holes in the wall and checkpoints are "zones of friction" in which colonizer and colonized come to know themselves within the hierarchies which sustain and are sustained by them.

For Azoulay and Ophir, when considering the wall's function, it is important to consider the relation between what they term spectacular violence (which kills instantly) and suspended violence.

The suspended violence is effective without bursting out because it forbids, deters, and delays, complicates simple actions, undermines preferences, undercuts daily schedules, drives people crazy and sometimes even kills. Its impact is more, not less disastrous than that of spectacular violence. ${ }^{17}$ 
The distinction, they write, is sometimes blurred, as when a soldier at a checkpoint (or a settler on a rampage) erupts into spectacular violence. Spectacular violence often “congeals" into suspended violence, as when they produce more troops, more checkpoints, and so on; conversely, suspended violence easily erupts into spectacular violence . Azoulay's and Ophir's understanding that the wall is "a seemingly perfect architectonic-geostrategic machine of suspended violence," 18 and their insight into the wall as "spatial segregation and reintegration through which conflict management is carried out by the ruling partner," rightly emphasize the importance of gates, openings and holes in the wall as spaces where performances of power occur. They insist (relying on Tal Arbel's phrase), nonetheless that in such spaces, there is a "measured abandonment," a disciplining of bodies that rarely shows its excess: "Bodies are touched, pushed, detained for hours but not penetrated or butchered, and the soldiers hardly ever shoot and very rarely use sticks.",19

I am less certain of the neat spatial and psychic separation between measured abandonment and more spectacular moments of violent excess such as torture, killings, and so on. The asymmetrical intimacies performed at the checkpoints and at holes in the wall are performed by dominant subjects whose anxieties about borders and control overwhelm and must be resolved through violence. While they are willing to grant that on a macro level, the spectacular and the suspended fold into each other, Azoulay and Ophir pay less attention to this 
melding on an intimate level. The checkpoint and the controls at openings in the wall involve rituals to be sure but they are rituals of violence. People die at checkpoints as they are prevented from seeking medical care. Routinely, they encounter humiliation and degradation. As I have written elsewhere about the rituals of violence evident in lynching, and in the sexualized violence meted out to Arab prisoners at Abu Ghraib, violence transforms racial power into something real. It offers, too, an intimacy that is otherwise forbidden but one which can be immediately repudiated through the act of violence. Through an act of violence, sameness can be disavowed at precisely the moment when it is too present a possibility.

Violence, in other words, dispels as nothing else can, any suspicion of a common humanity. ${ }^{20}$

\section{Conclusion: The Rose at the Checkpoint}

In the above online accounts young Palestinians' experience of checkpoints, I encountered the story of the rose at Surda checkpoint. Maher relates the story:

The occupation puts a rose outside the terminal. It is something weird. I don't know what it is supposed to symbolize. You don't know what to do when you see it. I would love to tear it apart. They put you in this misery and humiliating situation and then they confront you with this. It is not our hope - it is all that damages our hope. ${ }^{21}$

Ahmed Ayyesh, a 27 year old writes: "What is an even more revolting provocation is the rose 
they put at the side of the fortified checkpoint. They treat you as animals and then they show you roses." Amani Syam, 22 concludes: "It is a political issue, they also put that rose to make us more angry and frustrated. They play with our feelings." 22 The reactions of these young people to the rose, and their analysis of it, brings to mind the example related by Muneer Ahmed, a lawyer who assisted prisoners at Guantanamo Bay, including Omar Khadr, the Canadian teenager detained now for seven years. ${ }^{23}$ Ahmed described a new interrogation site at Guantanamo. The American military have prepared a room decorated the way they imagine a home in the Middle East. The room contains a hookah, an 'Oriental' carpet, and pistachio nuts in a bowl. Is the room supposed to remind Khadr and other Middle Eastern detainees of the home they missed? Is the orientalized interrogation room meant to play with the prisoners' feelings, as Syam thought of the rose, or is it also meant to offer the interrogators a brief excursion into otherness, simulated though it may be? Whatever its meaning, the rose at the checkpoint suggests that an encounter is in progress, a play for power full of ambivalence, obsession and fantasy.

It is possible to theorize the spaces of occupation and of the wall in particular in other ways besides those that tell of roses, holes in the wall and endless shouting. The story of Jeeb, for instance, could be told more clinically, with the reports of the Independent Media Center of Philadelphia. For the week of December 01-07, 2005, the centre notes: "During the reported period, IOF [Israeli Occupation Forces] razed areas of Palestinian agricultural land in al-Khader 
village, southwest of Bethlehem, and the villages of Prophet Samuel and al-Jeeb and Dahiat alBarid area near Jerusalem, to construct new sections of the wall." ${ }^{24}$ House arrests, demolitions, land seizures, extra-judicial executions, floating checkpoints, checkpoints arbitrarily closed, and the building of a walled-in bypass road on Al-Jeeb's lands are all detailed, with the time of each action noted with military precision in the 24 hour clock. Occupation is above all demanding, requiring the occupiers to expend considerable resources managing the encounter with the occupied. What does it mean to suture this report's clinical account of occupation to the accounts above - the man jumping from roof to roof at the hole in the wall, the woman climbing with her computer, the jeeps racing to intercept her, and the young people outraged by the rose and overwhelmed by the shouting? In attempting to bring together these accounts, I mean to suggest a reading of colonialism that focuses on its spatiality, on the physical encounter between colonizer and colonized, on the way that spaces express power arrangements that operate on the bodies of the colonized, turning them into small animals scrambling over rocks, or rats prodded and poked to make their way through a maze. Animals, it must be remembered, are driven by instinct and are by virtue of being non-rational, not of the modern. These same spatial arrangements confirm colonizers as rightful owners of the land, convincing them who they are. The shouting, the power to arbitrarily stop and search, these must assist the 18 year old soldier wielding a gun to banish the ghosts on the landscape, the Arab faces, the outlines of buildings, the old Arabic names - anything that suggests that in truth, the land is Arab land. 


\section{Bibliography}

Agamben, Giorgio. State of Exception. Translated by Kevin Attell. Chicago and London: University of Chicago Press, 2005.

Amnesty International, "Stolen Sisters - A Human Rights Response to Discrimination and Violence Against Indigenous Women in Canada. Ottawa: Amnesty International Canada, 2004.

Azoulay, Mariella and Adi Ophir, “The Monster's Tail,” pp. 2-27 in Against the Wall, ed. Michael Zorkin (London and New York: The New Press, 2005).

Bremner, Lindsay. "Border/Skin”, pp. 122-135. In Against the Wall. Israel's Barrier to Peace, editor Michael Sorkin. New York and London: The New Press, 2005.

Fanon, Frantz. The Wretched of the Earth. New York: Grove press, 1963.

Massad, Joseph "The "Post-Colonial” Colony: Time, Space, and Bodies in Palestine/Israel." In The Pre-occupation of Postcolonial Studies, eds. Fawzia Afzal-Khan and Kalpana SeshadriCrooks, eds. Durham and London: Duke University Press, 2000, p.311-346.

Mbembe, Achille. “Aesthetics of Superfluity,” Public Culture, 16(3), 2004:373-405.

Mohanram, Radhica. Black Body. Women, Colonialism and Space. Minneapolis: University of Minnesota Press, 1999.

Marton, Rucharma and Dalit Baum, "Transparent Wall, Opaque Gates,” pp. 212-223 in Against the Wall, ed. Michael Sorkin (London and New York: The New Press, 2005).

Mur 2004. Directed by Simone Bitton. Cine-Sud Production, France/Israel.

Razack, Sherene., editor. Race, Space and the Law: Unmapping a White Settler Society. Toronto: Between the Lines, 2002.

Razack, Sherene. Casting Out: The Eviction of Muslims from Western Law and Politics. Toronto: University of Toronto Press, 2008.

Said, Edward W. The Question of Palestine. New York: Vintage Books, 1992. 
Said, Edward W. Culture and Imperialism. New York: Alfred A. Knopf, 1993.

Shalhoub-Kevorkian, Nadera. Facing the Wall. Palestinian children and adolescents speak about the Israeli Separation Wall. Jerusalem: World Vision, 2007.

(Http://stopthewall.org/communityvoices/print1077.shtml accessed September 20, 2007))

(Http://www.phillyimc.org/en/2005/12/17743.shtml. Accessed September 20, 2007)

1. Professor, Sociology and Equity Studies in Education, The Ontario Institute for Studies in Education, University of Toronto, 252 Bloor Street West, Toronto, ON., Canada M6P 1H3. srazack@oise.utoronto.ca. I would like to thank Nadera Shalhoub-Kevorkian for her sharing her insight into colonial processes in Palestine. Gada Mahrouse and Leslie Thielen Wilson offered their own uncompromising views of the violence of colonialism and inspire me to name it.

2. Radhica Mohanram, Black Body. Women, Colonialism and Space. (Minneapolis: University of Minnesota Press, 1999); Sherene Razack, Race, Space and the Law: Unmapping a White Settler Society. (Toronto: Between the Lines, 2002).

3. Lindsay Bremner, "Border/Skin"in Against the Wall. Israel's Barrier to Peace, editor Michael Sorkin (New York and London: The New Press, 2005), p.123.

4. Ibid., p.130 (emphasis added).

5. Ibid., p. 131, emphasis added and note omitted.

6. Achille Mbembe, “Aesthetics of Superfluity," Public Culture, 16(3), 2004:p. 390.

7. Ibid., p.392.

8. Nadera Shalhoub-Kevorkian, Facing the Wall. Palestinian children and adolescents speak about the Israeli Separation Wall (Jerusalem: World Vision, 2007).

9. Frantz Fanon, The Wretched of the Earth (New York: Grove press, 1963), p.39.

10. Mur 2004. Directed by Simone Bitton. Cine-Sud Production, France/Israel.

11. I observed this moment on my first trip to the Wall in June, 2007. 
12. Achille Mbembe, "Aesthetics of Superfluity," Public Culture, 16(3), 2004:p. 391.

13. Http://stopthewall.org/communityvoices/print1077.shtml accessed September 20, 2007.

14. Fanon, 1963, p.38.

15. Rucharma Marton and Dalit Baum, "Transparent Wall, Opaque Gates," p214, in Against the Wall, ed. Michael Sorkin (London and New York: The New Press, 2005).

16. Ibid., pp.219-220.

17. Ariella Azoulay and Adi Ophir, "The Monster's Tail," p.5 in Against the Wall, ed. Michael Zorkin (London and New York: The New Press, 2005).

18. Ibid., p.11.

19. Ibid., p. 25 , notes 7 and 8 .

20. Sherene Razack, Casting Out: Race and the Eviction of Muslims from Western Law and Politics (Toronto: University of Toronto Press, 2008).

21. Http://stopthewall.org/communityvoices/print1077.shtml accessed September 20, 2007.

22. Ibid

23. Muneer Ahmed, presented at the Annual Meeting of Law and Society, Berlin, July 2007.

24. Http://www.phillyimc.org/en/2005/12/17743.shtml. Accessed September 20, 2007. 